\title{
Sixteenth Century Hospital Reform: Henri IV and the Chamber of Christian Charity
}

\section{DANIEL HICKEY}

Summary: Created in 1606, the Chamber of Christian Charity was intended to fund pensions for former army officers and amputated soldiers by reviewing the operations and expropriating surplus revenues from local charitable foundations - abbeys, monasteries, hospices and local hospitals. This article explores the reasons behind Henri IV's initiative and the new methods used - royal commissioners and a centralized approach - to try to resolve what was seen as a traditional problem of corruption and redundancy in French poor relief structures. It will analyse the difficulties encountered by the Chamber and the legal obstacles to the whole effort to intervene in local municipal and ecclesiastical institutions to show that the experiment never produced the anticipated results and was abandoned shortly after the king's assassination in 1610.

$T_{1}$

rying to stabilize his kingdom at the end of the Wars of Religion and reduce his army to a peacetime level of 10,000 men: ${ }^{1}$ these were the objectives which directed Henri IV toward a centralized policy of reviewing and suppressing small, inefficient local hospitals in order to use their funds to create pensions for former army officers and amputated soldiers. In a series of measures typical of Henri IV, traditional actions such as distributing pensions and pay-offs to former soldiers were used to alleviate the shock of demobilization at the same time that new methods - royal commissioners and a centralized approach - were used to expropriate what were perceived as the mismanaged local poor relief agencies which had been the object of regular royal decrees since early in the sixteenth century. The whole operation was intended to be used to increase the funding for military pensions. 
This experiment in redirecting poor-relief funds to former officers and soldiers was begun in July 1604 when a royal edict carried through on an earlier project by Henri III ordering that the "Maison des Enfants Rouges du Faubourg Saint-Marceau" in Paris should become the "Maison de la charité chretienne," a hospital entirely devoted to caring for poor gentlemen soldiers and for those handicapped during military service. ${ }^{2}$ Continuing along the lines of his predecessor's project and in certain respects going further, Henri IV, in June 1606, ordered that a special commission, the Chamber of Christian Charity (Chambre de la Charité chretienne), be set up to review the administration of the leproseries, hospitals and abbeys of the kingdom. The new aspect of the 1606 edict was the decision that in the cases where abuses were found in the functioning or management of the local institutions, this commission was to have the power to step in to reclaim the funds which had been embezzled or even to close down the hospital in question and transfer its resources to the Grand Aumonier of France who was to allocate the funds to the pensions of poor gentlemen, retired officers or physically handicapped soldiers. ${ }^{3}$

Although not entirely new - most of the project had been previously spelled out in letters patent issued by Henri III in October 1576 and December 1577 - the creation of the Chamber of Christian Charity represented a radical departure from previous attempts to review the management of local foundations for poor relief. Just as the numerous royal initiatives in the $1520 \mathrm{~s}, 1530 \mathrm{~s}$ and 1540s, Henri IV's 'reform' was aimed at making more efficient use of what the Crown saw as the inefficient and mismanaged resources of the local foundations for poor relief. Funded by capital and land donations often dating from the Middle Ages, these maladreries and hospitals were multipurpose; they were to receive lepers, treat the sick, lodge impoverished itinerants and succour the village poor. They operated side by side with institutions whose functions had been specifically limited by their founders, like the Easter Charity at Oppède in the Luberon which gave alms to the poor on Good Friday, or the foundations in the Périgueux for the distribution of foodstuffs on Mardi Gras and Pentecost. Royal authorities perceived these institutions as disposing of limited funds and staff, and contended that they had never been capable of adequately providing the multitude of services specified in their charters. Their role had always been limited to insufficient and indiscriminate hand-outs to vagabonds and to the village poor. ${ }^{4}$

Many of these institutions had been founded as leproseries and with the gradual elimination of the disease which they were founded to treat they were seen as redundant. The Crown calculated that a great number of such leproser- 
ies could be shut down and their funds put to more useful purposes. After all, in 1266, under Louis VIII, it had been calculated that there were over 2,000 of them in the kingdom, and there had been up to 43 in the diocese of Paris alone. ${ }^{5}$ The successors of these institutions were the principal targets of the expropriation attempts.

In 1543, an edict issued by Francis I ordered a census and inventory of the remaining leproseries and referred specifically to the problem of the mismanagement of these institutions. Judges were told to visit the maladreries and leproseries of their jurisdiction, inspect their charters, titles and financial accounts, look into their management and determine when and to whom their accounts were to be presented. When irregularities were found, they were to discharge incompetent and dishonest administrators, and replace them with two new governors to be named or elected by the community and to be chosen from among the honest, solvent bourgeois. These new administrators were to take over the management of the revenues of the institution presenting their accounts anually to the officials of the town or village. ${ }^{6}$

Going even further, an edict published two years later was specifically directed against religious-controlled hospitals, contending that they were even more poorly directed than the majority of small hospitals. The administrators and prelates who governed these institutions often ignored the intentions of their founders and constantly tried to reroute holdings and funds toward themselves or the members of their religious community. Under the pretext that they possessed the title to the heritage, the religious communities pretended that they could determine how it was to be used. According to the King this often led them to "defraud" the poor, refusing them the food and subsistence which was their due and driving them toward the cities of the kingdom where collections had to be made to feed the hordes of new immigrants. Again he asked local justice officials to visit the hospitals of their jurisdictions and look into these abuses. In the cases of corruption or of refusal to collaborate, they were to name new administrators and place the hospitals under the control of the town or village officials. ${ }^{7}$

All of the edicts were repeated at regular intervals throughout the sixteenth century. ${ }^{8}$ That the provisions asking local justice officials to review hospital operations were repeated in 1544, 1546, 1553, 1560, 1561, 1566 and 1579 indicates that the abuses referred to in these edicts continued to pose a major problem. But even more problematical was the apparent inability or resistance of local officials to carry through on the investigations. The fact that the onus was placed on local officials indicates that assistance was seen as essentially a local responsibility: it was understood that local communities 
should put their charities in order so that they would be able to care for their own poor and sick inhabitants. This principle was clearly stated in the Edict of Moulins in February 1566. The king ordered that the funds of local and rural hospitals should be "bel et bien depensés pour les pauvres," and that,

the poor of each city, town and village should be fed and cared for by those of the city, town or village of which they are natives and residents such that they will not wander off and request aid elsewhere. ${ }^{9}$

The text went on to state that the inhabitants of each community, according to their ability, should contribute to feed their poor and that the collections for that purpose should be carried out under the supervision of the mayors, councillors, consuls and parish officials. Should the poor need treatment for their illnesses in distant town or city hospitals they should obtain a certificate to that effect before leaving their village. ${ }^{10}$

By the end of the century it was clear that such a locally based approach to reviewing leproseries and hospitals was not working. Repeated edicts indicate that the Crown remained convinced that the outdated leproseries and mismanaged hospitals possessed considerable revenues which the local assistance efforts remained unable to exploit properly. By 1576 the urgency of finding ways to demobilize the troops assembled during the Wars of Religion led the Crown to examine the possibility of rerouting what they saw as poorly invested hospital funds to use them as a partial pay-off to the military. It was this project which Henri IV transformed into a centralized royal commission - the Chamber of Christian Charity.

What was the status of old and physically handicapped soldiers prior to the creation of the Maison de la Charite chretienne and the Chamber? As Jean-Pierre Bois has noted, it should be emphasized that the royal actions in 1604 , as throughout the seventeenth century, continued to confuse the notions of age, social hierarchy and physical handicaps due to wartime injuries. The 1604 edict applies to "gentilhommes," "estropiés," and "soldats vieux et caducs." This lumping together of different categories of former soldiers was typical of the approach which preceded the 1604 reform. ${ }^{11}$ From the thirteenth century on aid had been granted to old and amputated soldiers under the oblats; a system in which abbeys founded under a royal charter were made responsible for taking them in, feeding and caring for them. ${ }^{12}$ Under Francis I the oblat was extended to all elective abbeys as the number of old and injured soldiers increased. This increase in the numbers of injured and handicapped soldiers was also due to changes in the methods of warfare. The introduction of firearms and the large-scale use of cannons considerably increased the 
number of injuries and of wartime amputees. The need to provide for these men after their amputation was one of the objects of the new legislation. ${ }^{13}$

The system of granting refuge to old and injured soldiers in French abbeys was neither unanimously accepted nor approved by the institutions in question. The problem of uneven distribution plagued the system as the abbeys in the Paris area were overcrowded with veterans while the more distant institutions took in fewer and fewer old soldiers. Arguing that the morals and habits of the soldiers were incompatible with monastic life, most abbots tended to transform their obligations into monetary payments - pensions - which were granted to the old and amputated soldiers in order to care for them at home. Moreover, the places allocated to the oblats or lay-religious ("religieux laïs") in each abbey could also be occupied by servants or members of certain of the monk's families, such that there were not enough places or pensions for all the soldiers who had the right to receive them - this was the reason that Francis I had increased the number of abbeys responsible for granting such aid. ${ }^{14}$

Beyond these problems of adapting traditional responses to the new problems posed, there was the more wide-ranging challenge of reducing the royal army of 10,000 men and, of course, scaling down the numerous feudal armies. The size of the French army during a few months in 1548 prior to the treaty of Cateau-Cambrésis had approached 50,000 men and in 1562 on the eve of the Wars of Religion there were 28,000 enrolled. ${ }^{15}$ It is probable that the number of regular and irregular soldiers increased dramatically during the Civil and Religious wars, and to attain a lasting peace it was necessary to reduce these armies and to stimulate recovery to provide for the former soldiers who were to be demobilized. Three different measures were taken to try to create the impression that the Crown attributed great value to the services which the armies had rendered at the same time that their soldiers were being disbanded.

Initially, even as discussions of reducing the army were taking place, the king had already begun looking into measures to improve the treatment of old and injured soldiers. In May 1596 an arrêt obtained from the King's Council by Simon Le Musnier, "syndic des estropiés," ordered that soldiers be housed, fed and treated in the hospital which Henri III had turned over to their service by a 1577 edict. ${ }^{16}$ The second step was taken in 1604 when this same hospital was the object of an edict officially designating it as La Maison de la Charité chretienne to house poor gentlemen and amputated veterans. The document went on to establish the structure of the institution, granting it revenues to be expropriated from the surpluses reported in the annual accounts of local and 
regional hospitals, from the sums paid by the abbeys for the oblats, and from the legal fines which judges ordered to be paid to the poor. ${ }^{17}$ To preside over the institution and supervise the collection of its revenues, the edict created a 'bureau' composed of four officiers or "personnes notables" and of four gentlemen and old captains. They were to seek out the revenues for the institution and to decide upon the admission of the injured and amputated veterans and eventually to establish other houses and hospitals in the provinces. ${ }^{18}$ Finally, the difficulties experienced by this 'bureau' in carrying out the tasks specified in the edict seem to have led to the third initiative, the 1606 creation of the Chamber of Christian Charity - a veritable royal commission - which seemed to be better structured to carry out its responsibilities than the previous measures. As with the 1604 'bureau,' it was to expropriate all or portions of the funds held by abbeys, leproseries or mismanaged hospitals and to centralize the management of the oblat, traditionally dispensed by the abbeys.

The control of the Chamber by the direction of the French army was clear from the beginning and the Constable of Montmorency, himself, was appointed to draw up the list of poor gentlemen and handicapped soldiers who were to receive pensions: according to the text of the 1606 document, he was to study the gravity of the injury or amputation in each case, the date and place where the injury occurred and, on the basis of this inquiry, he was to recommend the amount of the annual pension to be attributed to each soldier. In drawing up this list Montmorency was to be aided by the Duke d'Épernon, Colonel of the French infantry. ${ }^{19}$

The lists of pensions to be paid were to be transmitted to the Chamber of Christian Charity, of which both Montmorency and Épernon were members along with the Cardinal du Perron, the Archbishop of Sens, who sat as Grand Aumonier, one Secretary of State, the Sieurs de Rochepot, Souvray and Château-Vieux, representing the military orders, four Maîtres de requête ordinaires, Louis Durant, Martin Langlois, Jean le Guay and Jacques Merault and four Councillors from the Grand Conseil, Defriches, Bautru, Guynet and de Bermont. ${ }^{20}$ At least seven of the above made up a legal quorum for the Chamber and they were to be convened and to meet under the direction of the Avocat de l'Hôtel du Roi, Gilles de Champhnon. ${ }^{21}$

These officials were to preside over the review and examination of the leproseries, poorly-administered hospitals and abbeys which were not respecting the oblat. They were to send commissioners to inspect the questionable institutions and order the procureurs-généraux to draw up a list of all the hospitals, leproseries, maladreries and abbeys of the kingdom, their 
locations and the amounts which the Chamber ordered them to pay in pensions. The 1606 edict noted that as a result of this review procedure, the judges could condemn, without appeal, any institution to pay up to 500 livres. ${ }^{22}$ This system functioned from 1606 to 1610: both the appeals heard by the Chamber and the decisions rendered are available in the holdings of the Archives Nationales. The appeals were numerous: for 1607 and 1609, the years for which the series is almost complete, there were respectively 395 and 480 appeals lodged, but these included frequent repetitions. ${ }^{23}$ The decisions concerning certain hospitals, like Mante or Beauvais, were appealed almost every two months during the entire existence of the reform, which indicates the resistance and obstacles faced by the commission.

In the functioning of the pension payments, the Grand Aumônier received lists of the soldiers whom Montmorency and Épernon judged eligible to receive allocations and these soldiers were accorded pensions from the lists of the amounts which the abbeys, hospitals and leproseries were ordered to pay. The pensions seem to have varied and although I could find none of the actual lists drawn up, appeal procedures indicate attributions of between 60 and 80 livres. ${ }^{24}$ With the exception of the revenues needed to operate the Maison de la Charité chretienne, the amounts assessed to local abbeys, leproseries and hospitals were never transferred to Paris: they were to be paid directly in pensions to the eligible poor gentlemen and amputated soldiers who lived in the region of each institution and who were given vouchers to be honoured by the local administrators. Again, the difficulties with the functioning of this system can be seen in the appeals addressed to the commission by individual soldiers who had been allocated pension vouchers which had been honoured by the local institutions.

Between 1606 and 1611241 former soldiers who had been allocated pensions from local abbeys or hospitals complained that they were not being paid and each of them generally lodged more than one appeal. At the same time these appeals indicate the institutions which had been ordered to expropriate funds. The former soldiers singled out 176 abbeys which were not respecting their vouchers compared to only eight hospitals or fifteen maladreries. For André Corvisier, the fact that there were not more protests probably suggests that the total number of pensions created was relatively modest, a far cry from the figure of several thousand estimated by Jean Marchal, and that the repetitions of the appeals show that few institutions actually paid the pensions assessed to them. ${ }^{25}$ It also becomes clear that the project of suppressing the mismanaged hospitals and maladreries became secondary to the goal of reappropriating the oblats owed by the abbeys. 
The appeals and legal procedures to delay and eventually block commission decisions appear to have seriously compromised the efforts to fund the military pensions. Almost immediately after the death of Henri IV, the whole experiment was ended. Funds were no longer to be transfered from lepers as well as the poor and sick toward poor gentlemen, amputated veterans and old soldiers. A 1611 arrêt by Louis XIII explained this decision noting that "experience has taught us that the ordinary expenses and the destruction of [hospital] buildings during the recent wars [troubles] were so great that the revenues of their foundations were totally insufficient and the review of their accounts produced too little revenue to be of any aid to future soldiers." The document went on to claim that the oblat was sufficient to maintain old and handicapped veterans. ${ }^{26}$ This arrêt was completed by 1612 patent letters which restated the necessity of continuing to review the accounts of local leproseries and hospitals, but ordered that the funds recuperated from these inspections should be returned to their original purpose of aiding lepers as well as the sick and the poor. ${ }^{27}$

Why did Louis XIII abandon the policy of according financial aid to old and handicapped veterans? The 1611 text argues that, beside the disappointing results of the attempts to expropriate abbey and hospital funds for the operation, there remained fundamental objections to the use of funds contributed to aid the lepers and the poor in order to pay veterans pensions. The document noted that lepers remained numerous in France and that the principal goal of the foundations was to come to their aid. Charitable groups underlined the fact that there were legal problems involved in using funds originally donated for one group in order to aid another. In addition, there were questions over the right of the Crown to order these transfers. If the initial measures were directed at abbeys and hospitals created by royal charters, the suppressions were soon extended to other institutions.

Traditionally the management of the hospitals had been one of the responsibilities of religious officials. While royal edicts and municipal authorities had tried to replace the ecclesiastics who governed hospitals during the first part of the sixteenth century, the Church had never accepted this new policy. The appeals lodged by the abbeys and hospitals against the expropriations and suppressions ordered by the Chamber frequently questioned the right of the king to intervene in hospital affairs and referred to the illegality of the whole procedure. It seems to have been the issue of legality rather than the poor results obtained by the commission which led Louis XIII to abandon the Chamber of Christian Charity. 
Certainly legal issues and royal rights rarely posed a major problem to Henri IV. As with most of the issues seen as creating royal absolutism, the king saw the question in eminently practical terms. The need to de-escalate and demobilize both royal and feudal armies and the necessity of retiring old soldiers and lodging amputees who otherwise could cause social disorder led him to reactivate Henri III's project of the Maison de la Charité chretienne to be financed from the long-contested foundations for lepers. Enlarging this project, he created a royal commission to review systematically the functioning of all the hospitals and leproseries of France in order to distribute veterans pensions from their unneeded funding. In all of this project, Henri IV paid little attention to his right to carry out such transfers or distributions, to the legal position of the original donors of the funds he ordered expropriated, or to the independent status of the hospitals whose management was contested. The legal and procedural obstacles confronted by this initial attempt at a centralized review of the budgets and the functioning of local institutions of charity in order to expropriate their "unneeded" funds was far from a resounding success. It could be questioned whether this failure was due to the incapacity of a primitive bureaucracy unable to touch local rights and privileges or to the clumsy structuring of the Chamber's mandate. In either case it certainly demonstrates the blocages to extentions of the Crown's power and the limits to the renewal of the "State" under Henri IV.

\section{Université de Moncton}

\section{Notes}

1. André Corvisier. Armées et sociétés en Europe de 1494 à 1789 (Paris: Presses Universitaires de France, 1976), p. 57.

2. Royal Edict, July 1604, Archives Nationales [hereafter AN] mm. 233. The creation of this Maison de la Charité chretienne followed through on an earlier project announced by Henri III in patent letters issued in October 1576 to create a home for old soldiers on the site of the Enfants Rouges, an institution to educate poor orphans. Henri III's patent letters announced several other elements of his successor's program, like a special commission composed of presidents of the Parlement de Paris to look into abuses in the administration of local hospitals. See "Lettres patentes," October 1576, AN, mm. 233.

3. Edict du Roy faict en faveur des pauvres gentilshommes ... (Paris, June 1606), AN, $A D+141$, pièce 4.

4. Robert Favreau. "La pauvreté en Poitou et en Anjou à la fin du Moyen Age," in Michel Mollat, ed. Études sur l'histoire de la pauvreté(Moyen Age-XVIe siècle), 2 vols. (Paris: Publications de la Sorbonne, 1974), 1, 589-620; Jean-Marc Bienvenu. "Pauvreté, misère et charité en Anjou aux XI' et XII ${ }^{\mathrm{e}}$ siècles," Le Moyen Age, 72 (1966), 389-425; Georges Duby. "Les pauvres des campagnes dans l'Occident médiéval jusqu'au XIII' 
siècle," Revue d'Histoire de l'Église de France, 52 (1966), 25-32; Michel Mollat. Les pauvres au Moyen Age (Paris: Hachette, 1978).

5. Michel Foucault. Histoire de la folie à l'âge classique (Paris: Plon, 1961), pp. 13-14.

6. "Edit attribuant aux baillis, sénéchaux et autres juges la surveillance de l'administration des hopitaux et maladreries," Fontainebleau, 19 December 1543, in Isambert et al. Recueil général des anciennes lois françaises depuis l'an 426 jusqu'à la Révolution de 1789, 29 vols. (Paris, 1827), XII, 841-43.

7. "Edit ordonnant que tous administrateurs d'hopitaux seront tenus de rendre compte aux prochains juges des lieux ...," St-Germain-en-Laye, 15 January 1545, in Isambert, XII, 897-900.

8. The Edict of Fontainebleau was repeated on 19 May and 17 June 1544, 26 February 1546, 12 February 1553, 25 July 1560, December 1560, April 1561, July 1566 and in 1579. The Edict of St-Germain-en-Laye was modified in the Edict of Rochefort, 26 February 1546, encouraging baillis and sénéchaux to establish commissioners in their jurisdictions to carry out the visits and reforms of the maladeries and hôpitaux.

9. "Ordonnance sur la reforme de la justice," Moulins, February 1566, in Isambert, XIV, 209.

10. Ibid, 210-1.

11. Jean-Pierre Bois. "Le vieillard dans la France moderne, XVII ème-XVIII ème siècles. Essai de problématique pour une histoire de la vieillesse," Histoire Économique et Sociale, 1 (1984), 76-77.

12. Geneviève Voitel-Grenon. "La Chambre de la generalle reformation des hopitaux, hotels-dieu et maladreries de France, 1612-1672," dissertation, École des Chartes (Paris, 1973), pp. 150-1.

13. Robert Chaboche has provided a very detailed study of handicapped soldiers during the Thirty Years War and there is no reason to believe that the problem was less evident during the Wars of Religion.. See "Les soldats français de la Guerre de Trente Ans, une tentative d'approche," Revue d'Histoire Moderne et Contemporaine, XX (janv.mars 1973), 11-24.

14. Claire Guérin. "Une tentative de réforme militaire et hospitalière, 1672-1693: son application en Normandie," dissertation, École des Chartes (Paris, 1975), p. 110.

15. Ferdinand Lot. Recherches sur les effectifs des armées françaises des Guerres d'Italie aux Guerres de Religion, 1492-1562 (Paris: SEVPEN, 1962), pp. 186 and 190.

16. Robert Chaboche. "Le sort des militaires invalides avant 1674," chapter II in Les Invalides. Trois siècles d'histoire (Paris: Musée de l'Armée, 1974), p. 130.

17. In his Economies, Sully noted the reasons for this royal intervention, "le roy n'estimant pas que des capitaines mal payez, des soldats négligez ... portassent jamais grande aimitié à ceux qui les emploieraient, ... se résolut de préparer des moyens pour lessouldoyer suffisament, et leur subvenir en leurs nécessitez, playes et maladies" (1604), in Sully, Economies, ed. Michaud, vol. 1, p. 620, col. 2.

18. Edit du Roy pour la création de la Maison de la Charité chretienne (Paris, July 1604), AN, mm. 233.

19. Edict du Roy faict en faveur des pauvres gentilshommes ... (Paris, June 1606), AN, $\mathrm{AD}+141$, pièce 4 , pp. 7-8. 
20. The names of the four Conseillers au Grand Conseil are not indicated in the edict, but they are listed on the first page of the "Premier registre de la Chambre de la Charité chretienne," samedi, 5 août 1606, AN, V7 148, fo 1 .

21. Ibid., ff. 10-11.

22. Ibid., ff. 12-13.

23. Minutes des enquêtes, 1607, AN, V7 126, 216 folios; 1609, AN, V7 127, 220 folios.

24. See François de la Barre vs l'Hôpital de Donzy, 19 November 1609, AN, V7 127; and Leonard Conault vs le Prieur de N-D de Jorgny, 31 March 1609, AN V7 127, fo 71.

25. André Corvisier,. "Anciens soldats, oblats, mortes-payés et mendiants dans la première moitié du XVII" siècle," $97^{e}$ Congrès National des Sociétés Savantes. Nantes, histoire moderne (Paris, 1977), vol. 1, 12-16 and 23-25.

26. Arrêt de Louis XIII, 1 September 1611, AN, AD+ 152.

27. Lettres patentes sur la reformation generalle des hôpitaux, hôtels-Dieu, maladreries et autres lieux pitoyables du Royaume, 24 October 1612, AN, AD XIV, 1. 